\title{
THE RELATIONSHIP BETWEEN THE PERCEPTION AND PRODUCTION OF FOUR GENERAL BRITISH VOWELS BY SLOVENE UNIVERSITY STUDENTS OF ENGLISH
}

\section{INTRODUCTION}

\subsection{Perception and Production of Vowels}

Successful acquisition of foreign sounds depends on several factors, among which the pivotal ones are the correct perception and production of the sounds. The ability to discriminate between L1 and L2 sounds is hindered by the phonemic and phonetic system of L1, since the judgements on similarity or difference between two phonemes are made against the background knowledge and phonemic awareness of the mother tongue.

It has been frequently suggested that there is a strong correlation between L2 perception and production of phonemes. Flege (1995) and Escudero (2000) both believe that the majority of production errors are based on a false perception of L2 phonemes. Regarding the development of new phonemic categories by L2 speakers, Flege (1995) and Best (1995) claim that foreign learners can create new L2 phonemes only by relying on some phonemic category of their L1. More recent studies by Baker and Trofimovich (2006) and Bion et al. (2006), which have looked into the relationship between the perception and production of L2 vowels, claim that there is a positive correlation between vowel perception and vowel production. Furthermore, they tentatively suggest that vowel perception might precede vowel production.

\subsection{Orthographic Input and Production of Sounds}

There has been very little research in second language acquisition on the influence of L1 orthography on the perception and production of L2 phonemes. Bassetti (2008) argues that orthographic input of L1 interacts with L2 acoustic input, leading to nonnative pronunciations which cannot be attributed to the influence of L1 phonological and phonetic system. The influence of L1 orthographic input can have positive as well as negative effects on L2 pronunciation. The positive influence of L2 orthography on L2 pronunciation lies in the visual representation (i.e. by means of letters) of a phonemic contrast, ${ }^{1}$ whereas the negative influences of L2 orthography are manifold (e.g.

\footnotetext{
* smiljana.komar@ff.uni-lj.si

1 Studies by Brown (1998) and Eckman (2004) have shown that Japanese learners of English can learn to distinguish between the phonemes $/ 1 /$ and $/ \mathrm{r} /$ if they know how a word is spelt; if it is spelt with the letter $<\mathrm{r}>$ they will pronounce it as $/ \mathrm{r} /$, if the word contains the letter $/ 1 /$, they will pronounce it as $/ 1 /$.
} 
additions and omissions of phonemes, phoneme substitutions and equations of L1 and L2 phonemes). The influence of L2 orthography on L2 pronunciation is present also when L2 learners are speaking freely.

The orthographic input seems to affect the correlation between perception and production as well. Research has shown that learners' mental representations of L2 phonemes created under the influence of orthographic input may affect their perception in such a way that they hear non-existing phonemes or phonetic features (see Matthews/ Brown 2004).

We can sum up that the mental representations of L2 phonemes created on the basis of orthography are so strongly imprinted in the brain that they affect the production and perception also in the absence of the orthographic input.

\subsection{Orthographic Input, Phonemic Transcription and Production of Sounds}

Phonemic transcription can be regarded as an important medium between a written text and its spoken manifestation. The International Phonetic Alphabet, which is used for the transcription of sounds, consists of symbols and diacritical signs with a number of symbols resembling letters. A quick look at different dictionaries of the English language shows that not all of them opted for the International Phonetic Alphabet. In fact, a large number of American dictionaries developed their own system for the transcription of English sounds which uses letters. As pointed out by Šuštaršič (2005: 94), this choice, although governed by the familiarity of letters, turned out to be confusing and not very user-friendly.

In agreement with the discussion above (see 1.2), we believe that speakers whose L1 exhibits a close grapheme-phoneme correspondence (e.g. Slovene) may benefit from phonemic transcription when they are learning foreign languages whose grapheme-phoneme correspondence is more opaque (e.g. English). Phonemic transcription, however, may also reflect many pronunciation errors which are the result of the orthographic input. Nonetheless, we believe that one of the most important roles of phonemic transcription is its ability to develop L2 phonetic awareness in L1 learners.

The importance and positive influence of phonemic transcription on the foreign learners' pronunciation has been researched and documented by, among others, Wells (1996), Šuštaršič (2005) and Lintunen (2005). The third of these studies has investigated the effect of phonemic transcription on L2 pronunciation in learners whose L1 exhibits a close phoneme-grapheme correspondence (Finnish) and found that the phonemic transcription generally has a positive effect on the pronunciation of a foreign language with an opaque phoneme-grapheme correspondence. The correlation between the phonemic transcription and the pronunciation of consonants was stronger than that between the phonemic transcription and vowels.

\subsection{GB Vowel System vs. Slovene Vowel System}

Studies in contrastive English-Slovene analysis of the vocalic system have shown that the two languages differ not only in the number of vocalic phonemes but also in their 
quality and quantity (see Šuštaršič/Komar/Petek 1995; Šuštaršič 2003, 2005; Stopar 2015). Stopar (2015: 87) presents the comparison between Slovene and GB monophthongs as shown in Figure 1.

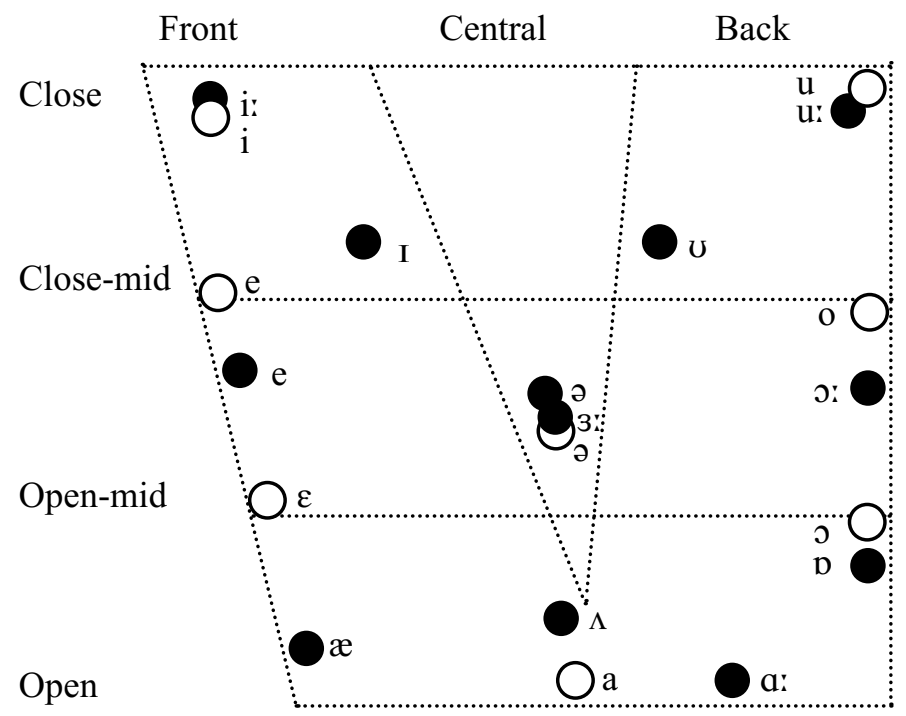

Figure 1: Vowel chart with Slovene (white dots) and GB (black dots) monophthongs

Several studies (Šuštaršič 2005; Stopar 2015) in contrastive analysis of Slovene and General British vowel systems have shown that the most difficult GB vowel contrast for Slovene speakers of English to master is the contrast between the front close-mid to open$\mathrm{mid} / \mathrm{e} /$ - or DRESS vowel - and the front just above open /æ/ - or TRAP vowel - (transcribed in Cruttenden (2014) as /a/). ${ }^{2}$ The contrast is even more challenging since there is a similar vowel contrast in standard Slovene between /e/ (front close-mid) and $/ \varepsilon /$ (front open-mid). The most common mistake that Slovene speakers make is to neutralize the GB vowel contrast and pronounce both vowels as the Slovene /E/. Šuštaršič (2005: 84) observes that this failure to distinguish between the two GB vowels is also present in the phonemic transcription exercises. The study by Stopar (2015: 89) shows that the perception of /e/ and /æ/ is least successful, and that the two vowels are most frequently heard as interchangeable.

\section{THE STUDY}

The present study investigates the influence of orthography and phonemic transcription on the production of the GB vowels $/ \mathrm{e} /, / \mathfrak{x} /, / \mathrm{N} /$, and $/ 3: /$. Its purpose is also to examine the correlation between the perception and the production of these four GB vowels. In this respect, the study is closely connected to the study by Stopar (2015) in terms of the choice of experiment material and the results.

2 DRESS, TRAP, STRUT and NURSE are four of 27 keywords introduced by Wells (1982) to represent a large number of words with the same vowel. 


\subsection{Research Questions}

The purpose of the study was to answer the following research questions:

RQ1: Does spelling by analogy guarantee correct pronunciation of the vowels in question?

RQ2: Does the training of phonemic transcription have a positive influence on the production of the four GB vowels $/ \mathrm{e} /, / \mathfrak{e} /, / \mathrm{L} /$, and $/ 3: /$ ?

RQ3: Does the production of the four vowels in question mirror their perception?

\subsection{Method and Participants}

The study consisted of two production tests. In the first test, which took place at the beginning of the course in English phonetics and phonology (October 2016), the participants were given a list of 24 orthographically transcribed English real and nonsense words. They were required to read and record them. They were also informed that some of the words were nonsense words, and that they should try and read them by analogy with the spelling. The second test took place at the end of the course (January 2017) - the course consisted of 30 hours of lectures and 30 hours of practical classes during which the students were trained in perception and production of General British phonemes, as well as in phonemic and phonetic transcription. ${ }^{3}$ The participants were given the same 24 real and nonsense words, but this time only phonemically transcribed.

The words used in the test, contained the four vowels in question. Each vowel was represented by six words. The DRESS -vowel words were $<$ gret $>/$ gret $/,<$ streb $>/$ streb/, $<$ tech $>/$ tek/, $<$ med $>/$ med/, $<$ bent $>/$ bent/, and $<$ fled $>/$ fled/. The TRAP-vowel words were represented by $<$ dap $>/$ dæp/, $<$ map $>/ \mathrm{mæp} /,<$ lag $>/$ æag/, $<$ kaln $>/ \mathrm{k} l n /$, $<$ badge $>$ /bæd//, and $<$ shazz $>/$ ææz/. The stRUT-vowel words were $<$ cut $>/$ k $\Lambda$ t $/,<$ numb $>$ $/ \mathrm{n} \wedge \mathrm{m} /,<$ fung $>/ \mathrm{f} \wedge \mathrm{y} /,<$ love $>/$ lıv $/,<$ come $>/ \mathrm{k} \wedge \mathrm{m} /$, and $<$ crup $>/ \mathrm{kr} \wedge \mathrm{p} /$. The NURSE-vowel words were represented by $<$ plurp $>$ pls:p/, <turg $>/$ t3:g/, <work $>/$ w3:k/, <lurk $>/$ ls:k/, $<$ bird $>/$ bs:d/, and $<$ heard $>/ \mathrm{h} 3: \mathrm{d} /$. The words were mixed and occurred in the following order: /dæp/, /kıt/, /pls:p/, /gret/, /mæp/, /nım/, /tz:g/, /streb/, /læg/, /fıy/, /ws:k/, /lıv/,

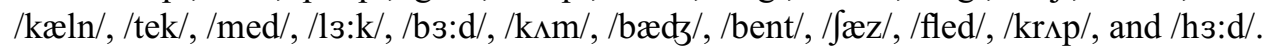

For the evaluation of results, the auditory method was used. The evaluator had vast and long experience in teaching British English phonetics and phonology to Slovene speakers of English.

All the participants in the study were first-year BA students of English at the Faculty of Arts, University of Ljubljana. In the first test 60 students took part, whereas in the second test only 40 students participated. Participation in the study was on a voluntary basis.

3 The practical teaching of English pronunciation to Slovene students of English consists of several strategies which include (i) different ear-training exercises whose purpose is to improve the learners' perception of GB phonemes, (ii) phonemic (and to some extent also phonetic) transcription of written texts, (iii) reading phonemically transcribed texts, and (iv) reading regular texts. All these strategies are supported by the theory of GB phonology and phonetics. 


\section{RESULTS}

\subsection{Reading from Orthography}

The average performance of the participants in the production of the four vowels in question when "reading from orthography" was at $74 \%$. Table 1 shows that the GB vowel /e/ was not problematic and was pronounced correctly by all participants. The weakest performance was, as expected, of the GB vowel/æ/, immediately followed by the GB vowel /3:/, and the GB vowel $/ \Lambda /$.

Table 1: Production of $/ \mathrm{e} /, / \mathfrak{x} /, / \Lambda /$, and $/ 3: /$ in reading from orthography by Slovene students of English $(\mathrm{N}=60)$

\begin{tabular}{|c|c|c|}
\hline GB Vowel & Correct (\%) & Substitutes (\%) \\
\hline /e/ & 100.0 & 0 \\
\hline$/ æ /$ & 49.0 & $\begin{array}{l}\text { /e/ (35.9) } \\
/ \mathrm{a}: /(15.1)\end{array}$ \\
\hline$/ \Lambda /$ & 79.3 & $/ \mathrm{a} /(20.7)$ \\
\hline /3:/ & 67.8 & /ər/ (32.2) \\
\hline Mean & 74.0 & \\
\hline
\end{tabular}

The analysis of the substitutes showed that the most common substitute for the GB vowel $/ \mathfrak{x} /$ was the front close-mid to open-mid GB vowel /e/ (35.9\%), whereas a small percentage (15.1\%) read the model words with the back open long GB vowel /a:/. This means that more than one third of all participants did not distinguish between the DRESS and the TRAP vowels.

Mispronunciations of the STRUT vowel as /a/ were also relatively frequent (20.7\%). The pronunciation of the NURSE vowel as /or/ (32.2\%) was considered wrong, since the model pronunciation for our students of English is the General British English where the post-alveolar approximant $/ \mathrm{r} /$ is pronounced only in pre-vocalic positions.

\subsection{Reading from Phonemic Transcription}

The average performance of the participants in the reading from phonemic transcription test was $85 \%$, which was $11 \%$ better than in the reading from orthography test. Table 2 shows that the GB vowel /e/ was correctly pronounced by all participants. The pronunciation of the GB vowel /3:/ improved in the sense that only $0.8 \%$ of participants still pronounced it as /ər/, while the majority managed to pronounce the vowel without the post-alveolar approximant $/ \mathrm{r} /$. The pronunciation of the GB vowel /æa/ also improved by $10.1 \%$ compared to the reading from orthography test, whereas the pronunciation of the GB vowel $/ \Lambda /$ remained nearly the same. 
Table 2: Production of $/ \mathrm{e} /, / \mathfrak{m} /, / \Lambda /$, and $/ 3: /$ in reading from phonemic transcription by Slovene students of English $(\mathrm{N}=40)$

\begin{tabular}{|c|c|c|}
\hline GB Vowel & Correct (\%) & Substitutes (\%) \\
\hline$/ \mathrm{e} /$ & 100.0 & 0 \\
\hline$/ \mathfrak{a} /$ & 59.1 & $\begin{array}{c}\text { /e/ }(35.8) \\
/ \mathrm{a}: /(5.1)\end{array}$ \\
\hline$/ \Lambda /$ & 81.7 & $/ \mathrm{\partial} /(18.3)$ \\
\hline$/ 3: /$ & 99.2 & $/ \mathrm{or} /(0.8)$ \\
\hline Mean & $\mathbf{8 5 . 0}$ & \multicolumn{1}{|c}{} \\
\cline { 1 - 2 } & \multicolumn{2}{|c|}{}
\end{tabular}

The analysis of the most frequent substitutes showed that the most common substitute for the GB vowel /æ/ remained the close-mid to open-mid GB vowel /e/ (35.8\%). Only a small number of participants $(5.1 \%)$ pronounced it as the back open long GB vowel /a:/. The number of participants who pronounced /æ/ as /e/ decreased (13.3\%) compared to the number of participants in the reading from orthography test $(24.3 \%)$.

\subsection{Reading Nonsense Words}

Table 3 shows the performance of the participants in reading nonsense words from orthography, as well as from phonemic transcription. The average performance of the participants in reading nonsense words from orthography was, as expected, lower (namely, by $3.1 \%$ ) compared to the performance in the reading from phonemic transcription test.

In both tests the participants were most successful in pronouncing the DRESS vowel. Nearly equally successful was the pronunciation of the NURSE vowel - where there was a small exception in the reading from orthography test where $2.5 \%$ of the participants pronounced the post-vocalic approximant $/ \mathrm{r} /$. The pronunciation of the STRUT vowel was successfully achieved in both tests (over $80 \%$ ), with the short central mid-close to mid-open vowel /a/ as the only substitute. As expected, the least successful pronunciation results were achieved with the TRAP vowel. There was a small increase in the pronunciation of the vowel in the reading from transcription test $(6.6 \%)$. This vowel also had two common substitutes - /e/ and /a:/ - thus indicating a similar trend as with the pronunciation of real words.

Table 3: Production of /e/, /æ/, / $/$, and /3:/ in Reading Nonsense Words from Orthography and from Phonemic Transcription

\begin{tabular}{|c|c|c|c|c|}
\hline GB Vowel & $\begin{array}{c}\text { Correct ortho- } \\
\text { graphy }(\%)\end{array}$ & $\begin{array}{c}\text { Substitutes } \\
(\%) \\
\end{array}$ & $\begin{array}{l}\text { Correct tran- } \\
\text { scription }(\%) \\
\end{array}$ & $\begin{array}{c}\text { Substitutes } \\
(\%)\end{array}$ \\
\hline /e/ & 100.0 & 0 & 100.0 & 0 \\
\hline$/ æ /$ & 36.7 & $\begin{array}{l}/ \mathrm{e} /(34.3) \\
/ \mathrm{a}: /(29.0)\end{array}$ & 43.3 & $\begin{array}{l}/ \mathrm{e} /(40.0) \\
/ \mathrm{a}: /(16.7)\end{array}$ \\
\hline$/ \Lambda /$ & 81.5 & $/ \mathrm{a} /(18.5)$ & 85.0 & /a/ (15.0) \\
\hline /3:/ & 97.5 & /ər/ (2.5) & 100.0 & 0 \\
\hline Mean & 78.9 & & 82.0 & \\
\hline
\end{tabular}




\section{DISCUSSION}

The results indicate that spelling by analogy does not guarantee correct pronunciation of all the vowels in question (RQ1). Least problematic is the vowel/e/ when spelt with the letter $<\mathrm{e}>$, whereas the most frequent spelling of the vowel $/ \mathfrak{a} /$ by means of $<\mathrm{a}>$ does not trigger the right pronunciation. ${ }^{4}$ The prevailing substitute is /e/. The substitute /a:/ is particularly frequent in nonsense words ( $29 \%)$, which can be attributed either to the influence of the spelling (letter $<\mathrm{a}>$ ) or to the tendency to maintain the TRAP/PALM opposition in General British pronunciation.

The results confirm that there is a positive influence of systematic training in phonemic transcription on the production of the four vowels in question by Slovene students of English (RQ2). This fact is particularly noticeable in the case of the NURSE vowel, where the regular mispronunciation of $/ 3: /$ in reading from orthography includes the post-vocalic approximant $/ \mathrm{r} /$. This error disappears when students read the NURSE vowel words from phonemic transcription. A positive influence of phonemic transcription on the production of the TRAP vowel words can also be observed, but to a much smaller degree. Although the most frequent substitutes for $/ \mathfrak{a} /$ remain /e/ and /a:/, a small increase in the number of mispronunciations of $/ \mathfrak{x} /$ as /e/ can be observed in the reading from transcription test.

The average result for the successful production of the GB vowels $/ \mathrm{e} /, / \mathfrak{x} /, / \mathrm{N} /$, and /3:/ in reading from orthography test is at $74 \%$ and is comparable to the average result for the successful perception of the same vowels in the study by Stopar (2015) where the average was at $71.1 \%$. More important for establishing the degree of overlap between perception and production (RQ3) are the correct results of individual vowels and their most frequent substitutes. Our results confirm that the TRAP vowel is the most difficult vowel for Slovene students to perceive, and even more difficult to produce. In the study by Stopar, $61 \%$ of the participants perceived the vowel correctly. In our study the percentage of correct pronunciation of the vowel is noticeably lower (49\%). In both studies the most frequent substitute is the GB vowel /e/ - with a frequency of $20.8 \%$ in the study by Stopar, and $35.9 \%$ in our study.

As far as the other three GB vowels are concerned, the results between the successful perception and production do not show a parallel trend. According to Stopar (2015: 90) the second most difficult GB vowel to perceive is $/ \mathrm{h} /$, followed by $/ \mathrm{e} /$, and $/ 3: /$. Our results suggest that the second most difficult vowel to produce is /3:/ if the target pronunciation is General British, followed by $/ \Lambda /$, whereas the pronunciation of $/ \mathrm{e} /$ is least problematic.

Comparing the two studies with regard to the vowel substitutes that the participants perceived and produced, we can find little overlap. If the participants misperceived the GB vowel $/ \Lambda /$ as $/ \mathfrak{x} /(17.8 \%)$, they most frequently mispronounced it as $/ \partial /(20.7 \%)$. While the Stopar study showed /æ/ to be the most frequent misperception of /e/, the participants in our study had no problems pronouncing the vowel correctly $(100 \%)$.

4 Students are explicitly told that the vowel $/ \mathfrak{x} /$ is in $99 \%$ of its occurrences spelt with the letter $<a>$ (see Cruttenden 2014:119). 
With regard to the production of nonsense words, our results do not suggest that they were any more challenging than real words - the average facility values were $78.9 \%$ for nonsense words in reading from orthography, $82.0 \%$ for nonsense words in reading from phonemic transcription, $76.7 \%$ for real words in reading from orthography, and $84.8 \%$ for real words in reading from phonemic transcription. This is different from the perception study by Stopar (2015: 89) in which the perception of nonsense words appeared to be particularly challenging and much worse compared to real words. This means that in the perception tests of real words the participants try to decode the words by means of recalling the mental representations which, as stated above (see 1.2 ), were arrived at on the basis of orthography, whereas in the perception tests of nonsense words, the participants have to rely on perception only.

\section{CONCLUSION}

The paper presents the influence of orthography and phonemic transcription on the production of the four GB vowels /e/, /æ/, /N/, and /3:/. In line with the study by Šuštaršič (2005), our results suggest that the orthography has a misleading influence on the pronunciation, particularly in the case of the GB vowel /3:/, where the students tend to pronounce the vowel followed by the post-vocalic approximant $/ \mathrm{r} /$. The orthography (the letter $<\mathrm{a}>$ ) does not provide a positive influence on the pronunciation of the GB vowel /æ/ which is most frequently mispronounced as /e/. There is, on the other hand, a positive correlation between the phonemic transcription and correct pronunciation of the GB vowels $/ \mathrm{e} /, / 3: /$ and $/ \Lambda /$. In spite of an increase in correct pronunciation of the GB vowel /æ/, this vowel remains most problematic for the Slovene students of English. The comparison of the perception and the pronunciation results does not suggest that the correct perception is a guarantee for the correct production of L2 sounds.

The results of the study could be useful for improving techniques for teaching pronunciation. In addition to the identification of foreign GB vowels without reliance on orthography, the reverse exercises could prove beneficial. Similarly, the use of nonsense words for the training of perception, as well as for developing the awareness of the spelling, may prove a useful and entertaining exercise.

\section{References}

BAKER, Wendy/Pavel TROFIMOVICH (2006) "Perceptual paths to accurate production of L2 vowels: the role of individual differences." International Review of Applied Linguistics in Language Teaching 44/3, 231-250. http://dx.doi.org/10.1515/ IRAL.2006.010

BASSETTI, Benedetta (2008) "Orthographic input and second language phonology." In: T. Piske/M. Young-Scholten (eds), Input Matters in SLA. Clevedon, UK: Multilingual Matters, 191-206.

BEST, Catherine. T. (1995) "A direct realist view of cross-language speech perception." In W. Strange (ed.), Speech Perception and Linguistic Experience: Theoretical and Methodological Issues. Baltimore: York Press, 171-203. 
BION, Ricardo A. H./Paola ESCUDERO/Andréia S. RAUBER/ Barbara O. BAPTISTA (2006) "Category formation and the role of spectral quality in the perception and production of English front vowels." Proceedings of Interspeech 2006. Pittsburgh: Interspeech, 1363-1366.

BROWN, Cynthia A. (1998) "The role of the L1 grammar in the L2 acquisition of segmental structure." Second language Research 14/2, 136-193. http://dx.doi. org/10.1191/026765898669508401

CRUTTENDEN, Alan (2014) Gimson's Pronunciation of English, Eighth Edition. London, New York: Routledge.

ECKMAN, Fred R. (2004) "From phonemic differences to constraint rankings: research on second language phonology." Studies in Second Language Acquisition 26/4, 513-549. http://dx.doi.org/10.1017/S027226310404001X

ESCUDERO, Paola (2000) "The Perception of English Vowel Contrasts: Acoustic Cue Reliance in the Development of New Contrasts." In: A. James/J. Leather (eds), New Sounds 2000: Proceedings of the Fourth International Symposium on the Acquisition of Second Language Speech. Klagenfurt: University of Klagenfurt, 122-131.

FLEGE, James. E. (1995) "Second language speech learning: theory, findings and problems." In: W. Strange (ed.), Speech Perception and Linguistic Experience: Theoretical and Methodological Issues. Baltimore: York Press, 233-277.

LINTUNEN, Pekka (2005) "Phonemic transcription and its effect on learning." Proceedings: PTLC2005. London: University College London, 1-4. www.ucl.ac.uk/

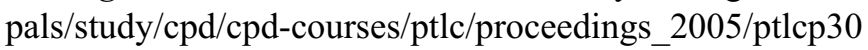

MATTHEWS, John/Cynthia BROWN (2004) "When intake exceeds input: Language specific perceptual illusions induced by L1 prosodic constraints." International Journal of Bilingualism 8/1, 5-27. http://dx.doi.org/10.1177/1367006904 0080010201

STOPAR, Andrej (2015) "Perception of Four General British Vowels by Slovenian University Students of English as a Foreign Language.” In: J. Przedlacka/J. Maidment/M. Ashby (eds), Proceedings of the Phonetics Teaching and Learning Conference, UCL, London, 5-7 August 2015. London: Phonetics Teaching and Learning Conference, 87-90. http://www.ucl.ac.uk/pals/study/cpd/cpd-courses/ ptlc/proceedings_2015/PTLC2015.pdf

ŠUŠTARŠIČ, Rastislav/Smiljana KOMAR/Bojan PETEK (1995) "Illustration of the IPA: Slovene." Journal of the International Phonetic Association 25/2, 135-139.

ŠUŠTARŠIČ, Rastislav (2005) English-Slovene contrastive phonetic and phonemic analysis and its application in teaching English phonetics and phonology. Ljubljana: Znanstveni inštitut Filozofske Fakultete.

ŠUŠTARŠIČ, Rastislav (2005) "Phonemic transcriptions in British and American dictionaries." ELOPE 2/1-2, 87-95. http://dx.doi.org/10.4312/elope.2.1-2.87-95

WELLS, John C. (1996) "Why phonetic transcription is important." Malsori (Phonetics), the Journal of the Phonetic Society of Korea 31-32, 239-242.

WELLS, John C. (1982) Accents of English. Cambridge: Cambridge University Press. 


\section{Abstract \\ THE RELATIONSHIP BETWEEN THE PERCEPTION AND PRODUCTION \\ OF FOUR GENERAL BRITISH VOWELS BY SLOVENE UNIVERSITY STUDENTS OF ENGLISH}

This paper presents a study of the influence of orthography and phonemic transcription on the pronunciation of the four GB vowels /e/, /æ/, / $/$, and / s:/ by Slovene university students of English. The paper also examines the relation between the perception and production of the four vowels in question by comparing the perception results of the same vowels from a previous study and the production results of this study. The results indicate a positive influence of phonemic transcription on the production of the examined vowels, whereas the influence of orthography on the pronunciation is confusing and leads to pronunciation errors. The results also confirm the findings of the perception study that the most difficult vowel contrast to maintain is between /e/ and /æ/. Interestingly, the perceived vocalic substitutes do not match the pronunciation substitutes for these two vowels. While the pronunciation of /e/ is excellent, its perception is still confused with $/ \mathfrak{æ} /$.

Keywords: phonemic transcription, GB vowels, perception of vowels, production of vowels, orthography

Povzetek

ODNOS MED PERCEPCIJO IN PRODUKCIJO ŠTIRIH SAMOGLASNIKOV STANDARDNE BRITANSKE IZGOVARJAVE PRI SLOVENSKIH UNIVERZITETNIH ŠTUDENTIH ANGLEŠČINE

$\mathrm{V}$ članku obravnavamo vpliv pisave in fonemske transkripcije na izgovarjavo štirih samoglasnikov standardne britanske angleščine /e/, /æ/, / /, in /3:/ pri slovenskih univerzitetnih študentih angleščine. Poleg tega tudi ugotavljamo odnos med percepcijo in produkcijo teh štirih samoglasnikov, tako da primerjamo rezultate predhodne študije percepcije teh samoglasnikov z našo študijo njihove produkcije. Rezultati kažejo pozitiven vpliv fonemske transkripcije na produkcijo preučevanih samoglasnikov, medtem ko je vpliv pisave na izgovarjavo zavajajoč in vodi do napak v izgovarjavi. Rezultati tudi potrjujejo ugotovitve študije percepcije, da je najbolj težavno prepoznavanje samoglasnikov /e/ in /æ/. Zanimivo pa je, da se pri tem samoglasniškem paru napačno zaznani samoglasniki ne ujemajo z napačno izgovorjenimi samoglasniki. Medtem ko je izgovarjava samoglasnika /e/ odlična, pa pri njegovi percepciji še vedno prihaja do zamenjave s samoglasnikom $/ æ /$.

Ključne besede: fonemska transkripcija, standardni britanski samoglasniki, percepcija samoglasnikov, produkcija samoglasnikov, pisava 